\title{
Pengelolaan Media Pembelajaran di Tingkat MI/SD
}

\author{
Yossi Fajriwasti ${ }^{1, a}$, Suci Indah Lestari ${ }^{2, b}$, Salman Alfarisi ${ }^{3, c}, *$ Sunarti $^{4, d}$ \\ 1,2,3,4 Pendidikan Guru Madrasah Ibtidaiyah IAIN Batusangkar, Sumatera Barat, Indonesia \\ Email: yossifajrii@gmail.com ${ }^{\mathrm{a}}$; suciindahlstr135@gmail.com ${ }^{\mathrm{b}}$; alfarisi0906@gmail.comc; \\ sunarti@iainbatusangkar.ac.id ${ }^{\mathrm{d}}$
}

\begin{abstract}
:
The management of learning media at the elementary school level is one of the supports to achieve the targeted learning outcomes. Media management is our way as educators/teachers to manage something that we will achieve in a program for providing learning media at the elementary school level. This research is a literature study that analyzes several sources, both books, journals, and other references to draw a conclusion as a result of the discussion. The results of the discussion found that there are four stages of learning media management, namely, media planning, media organizing, media implementation, and media evaluation. These four are management or management of media and learning resources at the MI and SD levels, so with the management of learning media, the learning process will run smoothly and effectively.
\end{abstract}

Keywords: Media management, Elementary School

\begin{abstract}
Abstrak:
Pengelolaan media pembelajaran dalam tingkat Sekolah Dasar menjadi salah satu penunjang untuk tercapainya hasil belajar yang telah ditargetkan. Pengelolaan media yaitu cara kita sebagai seorang pendidik/guru untuk mengelola sebuah hal yang akan kita capai dalam sebuah program penyediaan media pembelajaran ditingkat Sekolah Dasar. Penelitian ini merupakan penelitian kepustakaan yang menganalisis beberapa sumber baik buku, jurnal dan referensi lainnya untuk ditarik sebuah kesmpulan sebagai hasil pembahasan. Hasil pembahasan tersebut ditemukan bahwa ada empat tahap pengelolaan media pembelajaran yaitu, Perencanaan media, Pengorganisasian media, pelaksanaan media dan evaluasi media. Keempat tersebut merupakan manajeman atau pengelolaan media dan sumber belajar di tingkat MI mapun SD, maka dengan adanya pengelolaan media pembelajaran proses pembelajaran akan berjalan dengan lancar dan efektif.
\end{abstract}

Kata Kunci: Pengelolaan media, Sekolah Dasar

Cara mensitasi artikel ini:

Fajriwasti, Y., Lestari, S. I., Alfarisi, S., \& Sunarti, S. (2022). Pengelolaan media pembelajaran di tingkat MI/SD. Mitra PGMI: Jurnal Kependidikan MI, 8(1), 21-28. https://doi.org/10.46963/mpgmi.v8i1.424

\section{Informasi Artikel}

*Corresponding author:

sunarti@iainbatusangkar.ac.id

DOI:

https://doi.org/10.46963/mpgmi.v8i1.424

\author{
Histori Artikel: \\ Diterima : :16/11/2021 \\ Direvisi $: 15 / 01 / 2022$ \\ Diterbitkan : $31 / 01 / 2022$
}

\section{PENDAHULUAN}

Media pembelajaran merupakan sebuah sarana pembelajaran yang digunakan oleh seseorang dengan menggunakan alat yang dibuat untuk memudahkan dalam penyampaian materi ketika mengajar di sekolah. Hal seperti ini sangat membantu guru dalam mengajar di Sekolah dan merupakan solusi 
untuk membuat siswa senang ketika belajar dan tidak merasa jenuh. Melaksanakan kegiatan belajar mengajar tanpa menggunakan media pembelajaran dapat saja berjalan, akan tetapi tingkat keberhasilannya mungkin tidak setinggi ketika menggunakan media pembelajaran. Kita sebagai guru harus menguasai dan mampu menggunakan media pembelajaran untuk menunjang keberhasilan ketika proses belajar mengajar.

Peningkatan kualifikasi sekolah, pendidik dituntut memiliki pengetahuan yang cukup, mampu menyampaikan dan mempunyai sikap yang dapat dicontoh oleh siswa, serta keterampilan yang dimiliki secara holistic dapat bermanfaat dalam dunia pendidikan. Termasuk didalamnya mampu mengelola media pembelajaran, sehingga pembelajaran dapat diberdayakan terhadap komponen pembelajaran yang dimiliki sekolah. Keterampilan serta pengalaman yang dimiliki oleh seorang pendidik dalam mengikuti dalam mengikuti pelatihan, diharapkan dapat menindaklanjuti sehingga memberi kontribusi positif pada kemampuan guru dalam melaksanakan tugas pembelajaran dan mengelola seluruh komponen pembelajaran secara efektif.

Kepala sekolah sebagai salah satu komponen utama proses manajerial sekolah berfungsi sebagai pelopor di sekolah tersebut. Oleh karena itu kepala sekolah berkewajiban memotivasi, memonitoring serta mengevaluasi jalannya program sekolah, baik yang bersifat edukatif yang berhubungan dengan pengajaran maupun administrasi yang berkaitan dengan pengelolaan sekolah. Tugas tersebut sebagai satuan pendidikan yang ada di bawah tanggung jawabnya. Dengan kemampuan mempengaruhi, mendorong, membimbing, mengarahkan dan menggerakkan guru, staf dan siswa untuk bekerja atau berperan guna mencapai tujuan yang ditetapkan bersama. Sehingga diharapkan dapat menciptakan budaya sekolah yang kondusif dan mampu memotivasi para guru untuk senantiasa meningkatkan profesionalisme kerjanya dengan mengembangkan seluruh komponen pembelajaran secara maksimal, termasuk di dalamnya pengelolaan dan penggunaan media dalam pembelajaran.

Namun pada kenyataannya, masih banyak ditemukan para guru yang terlibat dalam pengelolaan media pembelajaran belum mengetahui secara menyeluruh terkait pengelolaan media pembelajaran. Hal ini berimbas pada manajemen media pembelajaran yang tidak maksimal. Berdasarkan pernyataan tersebut, maka perlu untuk memberikan pemahaman kepada para pendidik untuk terkait pengelolaan media pembelajaran di tingkat MI/SD yang akan dibahas secara lengkap dalam tulisan ini. 


\section{METODE PENELITIAN}

Penelitian ini menggunakan model penelitian kepustakaan. Teknik kepustakaan adalah penelitian kepustakaan yang dilakukan dengan cara membaca, mempelajari, dan mencatat berbagai literatur atau bahan bacaan yang sesuai dengan pokok bahasannya, yang kemudian di saring dan dituangkan ke dalam kerangka pemikiran teoritis. Metode penelitian ini bertujuan untuk mendapatkan data informasi melalui telaah teks dan buku referensi serta publikasi yang menjawab masalah yang sedang dibahas. Dalam penelitian ini, penulis ingin mengkaji hal-hal yang berkaitan dengan moderasi beragama sebagai upaya awal pembentukan sikap toleransi siswa sekolah dasar.

(Sari, 2020:45), Penelitian kepustakaan adalah penelitian yang mengumpulkan, membaca, dan mencatat kepustakaan/buku, untuk itu penelitian ini diambil dari berbagai sumber sebagai teks sastra yang relevan dengan bidang kajiannya . Sumber data yang digunakan adalah hasil penelitian sebelumnya yang relevan dengan topik yang dibahas. Langkah pertama dalam penelitian ini adalah mengumpulkan berbagai referensi atau data kepustakaan, kemudian membaca, mencatat, menganalisis dan membandingkan literatur yang ditemukan untuk diolah menjadi kesimpulan sebagai hasil penelitian ini. Dalam penelitian ini, data sekunder diambil dari jurnal ilmiah, buku teks, dan literatur review yang mengkaji topik yang sama. Penelitian merupakan penelitian analisis kebutuhan berupa sumbangan pemikiran dan dapat digunakan sebagai dasar kepribadian untuk menambah wawasan tentang moderasi beragama di tingkat sekolah dasar.

\section{HASIL DAN PEMBAHASAN}

\section{A. Konsep Pengelolaan Media dan Sumber Belajar MI/SD}

Pengelolaan dan sumber belajar, pengelolaan atau diartikan sebuah manajemen dapat dijabarkan sebagai usaha pengembangan agar proses pendidikan itu dapat berlangsung dan terencana, sehingga dapat menjadi cara pengendalian sebuah masalah agar terselesaikan dengan tepat, sedangkan sumber belajar merupakan sebuah konsep yang diperlukan untuk menunjang kegiatan belajar.

Pengelolaan atau manajemen yakni berupa cara kita untuk mengelola sebuah hal yang akan kita capai. Sedangkan sumber belajar merupakan sebuah konsep yang akan memudahkan dalam menunjang kegiatan belajar mengajar, jadi pengelolaan sumber belajar merupakan cara kita memanajemen sumber belajar seusai dengan kebutuhan dan sesuai dengan apa yang diajarkan. (Munisah, 2020)menyebutkan bahwa, manajemen media pembelajaran adalah bagian dari upaya meningkatkan kualitas pendidikan.

Cara yang dapat dilakukan dalam sebuah pengelolaan belajar ialah dengan berbagai cara atau melewati berbagai hal yakni bisa dilakukan dengan cara visual, 
dan alat Indera sehingga apa yang kita lihat, apa yang kita dengar dan apa yang kita rasakan semuanya akan menjadi sebuah sumber belajar. Tidak hanya sebuah buku di zaman Millennium. Setiap instansi sekolahan pasti mempunyai sarana sendiri untuk menghasilkan sumber belajar yang mumpuni. Jika berbicara tentang cara pengaplikasiannya bisa melalui banyak hal, di mana sumber belajar merupakan sebuah sarana peserta didik untuk paham dalam sebuah pembelajaran. Sarana prasarana, pengetahuan guru serta motivasinya. Sumber belajar merupakan alat untuk memahamkan peserta didik sehingga, guru di sini sangat berperan sangat penting dalam sebuah sumber belajar, guru dituntut untuk inovatif dalam mengembangkannya. Sehingga peserta didik dapat bermain sekaligus belajar, keadaan ini dapat dicontohkan pada sebuah buku cerita, Gambar-gambar dan sumber yang lain yang dapat memahamkan peserta didik.

Penggunaan media ini sangat diperlukan apalagi pada masa pandemi seperti saat ini, yang mana proses pembelajaran tidak terlaksana secara langsung dalam ruang kelas, dan penyampaian informasi kepada peserta didik sangat terbatas, maka sangat dibutuhkan penggunaan media pembelajaran yang maksimal dan itu perlu pengelolaan dari sekolah. (Ina dkk, 2021: 439) menyebutkan bahwa, penggunaan media dalam pembelajaran dapat membantu keterbatasan pendidik dalam menyampaikan informasi maupun keterbatasan jam pelajaran di kelas. Jadi penggunaan media ini akan mengefisienkan proses pembelajaran menjadi lebih maksimal, dan menjadikan media sebagai salah satu bahan ajar yang sangat dibutuhkan.

Tidak dapat dipungkiri bahwasanya bahan ajar atau sumber belajar merupakan sebuah unsur yang tidak dapat ditinggalkan. Bahan ajar merupakan aspek terluar dari proses mengajar yang dapat di gunakan sebagai tolak ukur peserta didik. Peran bahan ajar sangat penting dalam berjalanya proses pembelajaran, dan sebagai tujuan utama kompetensi yang akan dicapai peserta didik. Seorang guru akan memilih dan memilah bahan ajar apa yang tepat untuk apa yang akan diajarkan, dapat melalui media elektrik maupun non elektrik yang dapat menunjang hasilnya dikemudian hari. Permasalahan yang menyulitkan para guru saat ini adalah semakin canggihnya teknologi sehingga semakin cepat berkembangnya, dan diharuskan guru mengetahui akan hal itu. Di samping hal itu guru wajib mengarahkan keseluruhan kemampuannya untuk mengubah cara mengejar yang dulu menjadi cara mengajar di zaman sekarang, dengan menggunakan teknologi serta guru dapat merencanakan sebuah inovasi yang inovatif untuk menghasilkan produk-produk unggulan. 


\section{B. Proses Pengelolaan Media dan Sumber Belajar}

Proses pengelolaan media pembelajaran secara garis besar meliputi perencanaan, pengorganisasian, pelaksanaan pengelolaan, dan evaluasi terhadap pengelolaan media pembelajaran. (Munisah, 2020). Secara lebih rinci proses pengelolaan media dan sumber belajar menurut (Mulyasa, 2013)adalah sebagai berikut:

\section{Perencanaan Media Pembelajaran}

Penyusunan program kegiatan media pembelajaran sangat penting dibuat untuk menentukan kegiatan yang akan dilakukan selama kurun waktu tertentu, misalnya satu tahun. Kegiatan ini sangat membantu dalam mengatur jadwal penggunaan media serta persiapan alat/bahan yang diperlukan.

Merencanakan dana kegiatan operasional, perawatan/perbaikan, dan pengadaan media pembelajaran sesuai dengan kebutuhan siswa merupakan salah satu bagian dari perencanaan media pembelajaran sekolah. Perencanaan kegiatan media disesuaikan dengan kebutuhan siswa dengan asumsi bahwa guru adalah personal yang paling utama terhadap media menjadi tanggung jawab para guru, guru mendapatkan keleluasaan untuk menyusun program media dan menentukan media apa yang akan digunakan. Penggunaan media pembelajaran di dalam kelas harus direncanakan dengan sebaik-baiknya, meskipun dalam merencanakan penggunaan media pembelajaran tersebut guru diberi keleluasaan untuk memilih dan mengembangkan media pembelajaran sesuai dengan potensi, kebutuhan dan kemampuan peserta didik, serta kebutuhan masyarakat di sekitar sekolah. Oleh karena itu guru harus dapat memahami, menerjemahkan dan menjabarkan isi kurikulum yang akan ditransformasikan kepada peserta didik, karena kurikulum dapat digunakan sebagai perantara bagi guru dan peserta didik dalam proses pengalihan atau transformasi yang berlangsung melalui sebuah kegiatan yang disebut pembelajaran. Dalam proses pembelajaran ini terjadi interaksi antara peserta didik dengan seluruh komponen pembelajaran.

\section{Pengorganisasian Media Pembelajaran}

Pengorganisasian adalah pengelola/ pengurus media pembelajaran yang terdiri dari kepala sekolah, petugas media pembelajaran, dan kelompok jabatan fungsional. Pentingnya pengelolaan media untuk dilakukan, yang menitikberatkan pada aspek administrasi siswa, ketenagaan, sarana prasarana, pembiayaan, dan peran serta masyarakat. Program peningkatan kualitas proses belajar mengajar dengan 
mengoptimalkan pemanfaatan media dalam pembelajaran, kesediaan media berupa alat peraga mata pelajaran yang sesuai dengan jenjang kelas dan materi pembelajaran di setiap kelas, pembagian waktu penggunaan media pembelajaran yang disesuaikan dengan jadwal pelajaran, serta aktifitas dan prosedur penggunaan media dilaksanakan sesuai dengan ketentuan yang telah ditetapkan.

Berkenaan dengan pengelolaan media pembelajaran, hasil kegiatan pengelolaan organisasi ini berupa profil bentuk struktur atau susunan organisasi, baik susunan organisasi eksternal maupun internal. Susunan organisasi eksternal menggambarkan struktur organisasi pengelola media pembelajaran, sedang susunan organisasi internal menggambarkan bagian/bidang yang ada dalam pengelolaan media pembelajaran, hubungan tata kerja, tugas dan fungsi masing-masing bagian/bidang. Orang-orang yang terlibat langsung dalam pengelolaan media pembelajaran secara umum adalah kepala sekolah, penanggung jawab teknis kegiatan sesuai dengan bidang masing-masing.

\section{Pelaksanaan Pengelolaan Media Pembelajaran}

Kegiatan pelaksanaan pengelolaan media pembelajaran meliputi: pengadministrasian media pembelajaran, memilih dan menyiapkan media yang akan digunakan, menggunakan media dalam pembelajaran, serta mengatur/menata media pembelajaran.

\section{Evaluasi Pengelolaan Media Pembelajaran}

Petugas/pengelola media bertanggung- jawab atas segala kegiatan manajemen media pembelajaran. Kegiatan evaluasi dan pelaporan merupakan kewajiban yang harus dilakukan setiap pelaku manajemen media pembelajaran di sekolah. Dengan melakukan evaluasi akan dapat mengetahui ketercapaian program yang telah dirumuskan. Hasil evaluasi ini dapat dijadikan tolok ukur keberhasilan sekaligus mengungkap kekurangan selama proses berlangsung yang dapat digunakan sebagai bahan masukan, pertimbangan, dan pedoman dalam menyusun program media pada tahun berikutnya. Monitoring/pengawasan hendaknya dilakukan secara terprogram oleh kepala sekolah dan personal pada instansi terkait dari Dinas di tingkat kecamatan dan kabupaten untuk mengungkap temuan- temuan, faktor penghambat, dan kondisi yang diharapkan agar dapat dijadikan sebagai masukan untuk menentukan langkah kerja dan pengembangan pengelolaan media pembelajaran agar intensitas penggunaan media dalam pembelajaran demi peningkatan mutu pendidikan dapat terwujud. 
Dengan demikian diharapkan evaluasi dapat menghindari terjadinya penyimpangan-penyimpangan untuk menjamin tercapainya tujuan karena dengan melakukan evaluasi akan memperoleh fakta bagi yang biasa dijumpai serta kondisi yang diharapkan tentang media pembelajaran baik ditinjau dari aspek keberadaan media, pengelola media, maupun pengelolaan media pembelajaran. Pada akhirnya kegiatan evaluasi dapat menyediakan informasi dasar guna merancang ulang program yang dilaksanakan sekaligus perolehan informasi yang berharga untuk perumusan dan perancangan kembali suatu program maupun pengambilan keputusan yang akhirnya dapat meningkatkan kinerja guru dalam mengelola media pembelajaran.

\section{KESIMPULAN DAN SARAN}

Pengelolaan media pembelajaran sebagai bagian dari upaya meningkatkan kualitas pendidikan. Adapun indikator yang harus diperhatikan dalam pengelolaan media pembelajaran khusus di Sekolah Dasar adalah:

1. Perencanaan media pembelajaran merupakan bagian integral dari program sekolah untuk itu perlu melibatkan seluruh komponen sekolah, baik personal intern maupun ekstern sekolah, diharapkan penyusunan program media dapat berjalan searah dengan program pembelajaran yang telah dibuat sehingga dapat memberi kontribusi positif terhadap pembelajaran.

2. Proses pengelolaan media pembelajaran harus berjalan seiring dengan program sekolah, perlu dibentuk kepengurusan/ pengelola media pembelajaran di SD yang bertanggung jawab dalam mengadministrasikan semua kegiatan yang berkaitan dengan pengelolaan media pembelajaran.

3. Pemahaman dan pengetahuan tentang pengelolaan media penting bagi petugas dalam merencanakan program media, pengklasifikasian media, pengelompokan media berdasarkan kondisi sekolah masing-masing atau berdasarkan mata pelajaran tertentu agar media dapat digunakan secara optimal di dalam kelas maupun di tempat penyimpanan..

4. Monitoring/pengawasan hendaknya dilakukan secara terprogram oleh kepala sekolah dan personil pada instansi terkait dari dinas di tingkat kecamatan dan kabupaten diharapkan sebagai bahan masukan peningkatan pengembangan pengelolaan media pembelajaran pada tahun berikutnya.

\section{REFERENSI}

Anwar, K., \& Harmi, H. (2011). Perencanaan Sistem Pembelajaran KTSP. Bandung Alfabeta.

Depdikbud, (2011). Penyelenggaraan Pendidikan di SD. Jakarta: Depdagri, Ditjen Pemerintahan Umum dan Otonomi Daerah. 
Mitra PGMI: Jurnal Kependidikan MI

Vol. 8 No. 1 Tahun 2022

Fattah, N. (2010). Landasan Manajemen Pendidikan. Bandung: PT Remaja Rosdakarya.

Hamalik, O. (2014). Media Pendidikan. Bandung: PT Citra Abditya Bakti.

Majid, A. (2007). Perencanaan Pembelajaran: Mengembangkan Standar Kompetensi Guru. Bandung: Rosda Karya.

Mulyasa, E. (2013). Manajemen Berbasis Sekolah Konsep, Strategi dan Implementasi. Bandung: PT. Remaja Rosdakarya.

Munisah, E. (2020). Pengelolaan Media Pembelajaran Sekolah Dasar. Jurnal Elsa, 20.

Rahardi Aristio, (2013). Media Pembelajaran. Jakarta: Depdiknas, Dirjen Dikdasmen Direktorat Tenaga Kependidikan.

Sadiman, A. S., dkk. (2010). Media Pendidikan Pengertian Pengembangan dan Pemanfaatan. Jakarta: CV Rajawali.

Sudjana, N (2012). Media Pengajaran. Bandung: CV Sinar Baru Algesindo.

Wibawa, B (2010). Media Pengajaran. Jakarta: Depdikbud Ditjen Dikti PPTK.

28 Print - ISSN: 2443-0021

Online - ISSN: 2716-4136 